\title{
KEEFEKTIFAN MODEL PEMBELAJARAN BERBASIS PROYEK TERHADAP KEMAMPUAN MENULIS SISWA KELAS VIII SMP NEGERI 33 MAKASSAR
}

\author{
Akram Budiman Yusuf \\ Pendidikan bahasa dan Sastra Indonesia, FKIP Universitas Muhammadiyah Makassar \\ Email: akrambudimanyusuf@gmail.com
}

\begin{abstract}
Abstrak
Penelitian ini bertujuan untuk menguji keefektifan model pembelajaran berbasis proyek terhadap kemampuan menulis puisi siswa kelas VIII SMP Negeri 33 Makassar. Data-data penelitian ini diperoleh dari nilai hasil belajar sebelum perlakuan (pre-tes) untuk mengetahui kemampuan menulis puisi siswa dan skor postes untuk mengetahui kemampuan puisi siswa berdasarkan kesesuaian isi dengan tema, imaji, diksi, bahasa figurative/gaya bahasa, dan tipografi dengan menggunakan model pembelajaran berbasis proyek. Hasil analisis data pretest diketahui bahwa kemampuan menulis puisi diketahui belum memadai karena jumlah siswa yang mendapat nilai 70 ke atas belum mencapai $85 \%$ dan kemampuan menulis puisi posttest sudah memadai karena jumlah siswa yang mendapat nilai 70 ke atas sudah mencapai $85 \%$. Hasil analisis inferensial juga menunjukkan bahwa rata - rata gain ternormalisasi tampak bahwa nilai sig. (2tailed) adalah 0,000 yang mana $0,000<0,05$ sehingga dapat disimpulkan bahwa $\mathrm{H}_{0}$ ditolak dan $\mathrm{H}_{1}$ diterima yang berarti bahwa rata - rata peningkatan hasil belajar siswa $\geq 30$. Selain itu hasil analisis statistik inferensial juga menunjukkan bahwa pengujian ketuntasan siswa secara klasikal yang dilakukan dengan menggunakan uji proporsi dengan taraf signifikan 5\% diperoleh $\mathrm{Z}$ tabel = 1,64 yang mana $\mathrm{H}_{0}$ diterima jika $\mathrm{Z}$ hitung $\leq 1,64$. Karena diperoleh nilai $\mathrm{Z}$ hitung sebesar 2,017 maka $\mathrm{H}_{1}$ diterima dan $\mathrm{H}_{0}$ ditolak yang berarti ketuntasan siswa secara klasikal $\geq 85 \%$.Sehingga dapat disimpulkan bahwa penggunaan model pembelajaran berbasis proyek terhadap kemampuan menulis puisi memenuhi kriteria efektif.
\end{abstract}

Kata kunci: model pembelajaran berbasis proyek, menulis puisi

\begin{abstract}
This study aims to test the effectiveness of project-based learning model on the ability to write poetry students of class VIII SMP Negeri 33 Makassar. The data of this research are obtained from the value of learning result before the treatment (pre-test) to know the ability of student poetry writing and postes score to know the poem ability of the students based on the conformity of the content with theme, image, diction, figurative language / language style and typography with using a project-based learning model. The result of pretest data analysis is known that the ability to write poetry is not enough yet because the number of students who score 70 and above has not reached $85 \%$ and the ability to write posttest poem is adequate because the number of students who scored 70 upward has reached $85 \%$. The result of inferential analysis also shows that the normalized gain average appears that the sig value. (2-tailed) is 0,000 which is $0.000<0.05$ so it can be concluded that $\mathrm{HO}$ is rejected and $\mathrm{H} 1$ is accepted which means that the average increase in student learning outcomes $\geq 30$. In addition the results of inferential statistical analysis also indicate that students' which is performed by using a proportion test with a significant level of $5 \%$ obtained $Z$ table $=1.64$ where $H 0$ accepted if $Z$ arithmetic $\leq 1.64$. Because the value of $\mathrm{Z}$ arithmetic is 2.017, $\mathrm{H} 1$ is accepted and $\mathrm{HO}$ is rejected, which means student completeness in classical $\geq 85 \%$. So it can be concluded that the use of project-based learning model on the ability of writing poetry meet the criteria effectively.
\end{abstract}

Keywords: project-based learning model, writing poetry 


\section{PENDAHULUAN}

Pembelajaran sastra, terdapat empat aspek kegiatan yang harus diketahui dan dimiliki oleh siswa, yaitu aspek menyimak, berbicara, membaca, dan menulis. Pada aspek menyimak, siswa diharapkan mampu memahami dan mengapresiasikan ragam karya sastra. Pada aspek menulis, siswa diharapakan mampu menulis dan menentukan karya sastra yang diminati, baik itu puisi, prosa, maupun drama (Depdiknas:2006). Kegiatan menulis khususnya menulis puisi merupakan salah satu hasil dari karya sastra. Dalam menulis sebuah puisi harus dituangkan daya kreativitas yang ada dalam pikiran, perasaan, dan benak yang dituangkan dengan model bahasa dalam bentuk tulisan. Bahasa yang digunakan untuk membuat karya sastra puisi menggunakan bahasa yang khas dan berbeda dengan bahasa yang dipakai dalam drama dan fiksi karena penyair ingin mengekspresikan pengalamanya secara padat dan intens.

Pembelajaran menulis puisi menjadi salah satu kompetensi yang wajib ditempuh pada jenjang SD-SMA. Pada kenyataanya, terdapat suatu yang salah dan menjadi penghambat dalam pembelajaran sastra. Pada saat proses apersepsi siswa kurang diarahkan untuk lebih ekspresif, kreatif dalam mengembangkan karya sastra. Ketika mengajar di dalam kelas, kita sebagai pengajar dituntut untuk kreatif dalam memilih metode atau model yang akan digunakan dalam mengajar sehingga menunjang keberhasilan siswa. Salah satu cara untuk mengatasinya adalah dengan menggunakan model yang beragam dan bervariatif sehingga menarik minat siswa. Siswa menjadi aktif, kreatif, dan menciptakan suasana kelas yang nyaman. Hal tersebut dimaksudkan dapat membantu peserta didik berperan aktif dalam pembelajaran. Melalui model pembelajaran berbasis proyek, diharapkan dapat menciptakan suasana belajar yang lebih menyenangkan bagi siswa. Sementara itu, guru dapat lebih mudah dalam membimbing siswa. Model pembelajaran berbasis proyek adalah model pembelajaran yang menggunakan proyek/kegiatan sebagai media. Siswa melakukan eksplorasi, penilaian, interpretasi, sintesis, dan informasi untuk menghasilkan berbagai bentuk untuk hasil belajar (Munirah, 2015: 55).

Berdasarkan pengamatan yang telah dilakukan penulis, siswa kurang tertarik dengan kegiatan menulis khususnya menulis puisi. Siswa kurang mampu mengungkapkan ide, perasaan, dan gagasan yang ada dalam benaknya ke dalam sebuah tulisan. Siswa lebih tertarik terhadap bentuk pembelajaran yang efisien, efektif, dan menarik bagi siswa. Oleh karena itu, penulis tertarik untuk menggunakan model pembelajaran berbasis proyek sebagai model pembelajaran menulis puisi bebas bagi siswa. Model pembelajaran berbasis proyek ini dipilih untuk merangsang ide, gagasan, dan daya kreatifitas yang ada dalam benak siswa yang dituangkan dalam sebuah tulisan. Berdasarkan hal tersebut penulis tertarik melaksanakan penelitin di SMP Negeri 33 Makassar untuk menguji kemampuan menulis siswa menggunakan model pembelajaran berbasis proyek.

Berdasarkan pernyataan di atas, penulis memilih menulis puisi bebas dengan menggunakan model pembelajaran berbasis proyek. Menulis puisi dengan tema bebas karena sesuai kompetensi dasar mengenai menulis kreatif puisi. Penulis tertarik menggunakan model pembelajaran berbasis proyek untuk meningkatkan kemampuan menulis puisi siswa. Model pembelajaran berbasis proyek dianggap model pembelajaran yang paling efektif dan efisien dalam upaya meningkatkan kemampuan menulis puisi bagi siswa. Jadi penulis ingin mengetahui Keefektifan Model Pembelajaran Berbasis Proyek terhadap 
Kemampuan Menulis Puisi Siswa Kelas VIII SMP Negeri 33 Makassar.

Penelitian yang relevan pernah dilakukan oleh Dewi Astuti, dkk (2015) dengan judul penelitian "Keefektifan Model Pembelajaran Berbasis Proyek dalam Meningkatkan Kompetensi Menyusun Teks Cerita Prosedur Siswa Kelas VIII". Hasil penelitiannya menunjukkan bahwa pembelajaran dengan model berbasis proyek efektif dalam meningkatkan kompetensi sikap kemandirian, pengetahuan, dan keterampilan menyusun teks cerita prosedur kelas VIIII dilihat dari hasil uji n-gain aspek sikap secara klasikal meningkat dengan kategori rendah sebesar 0,26 aspek pengetahuan secara klasikal meningkat dengan kategori sedang sebesar 0,51 dan aspek keterampilan secara klasikal meningkat dengan kategori sedang sebesar 0,52 .

Model pembelajaran berbasis proyek adalah model pembelajaran yang memberikan kesempatan kepada siswa untuk menggunakan unit-unit kehidupan sehari-hari sebagai bahan pelajaran agar siswa tertarik untuk belajar. Adapun langkah-langkah model pembelajaran berbasis proyek (Munirah, 2015: 59) sebagai berikut:

a) Penentuan pertanyaan mendasar

Pembelajaran dimulai dengan pertanyaan esensial, yaitu pertanyaan yang dapat memberikan penugasan siswa dalam melakukan suatu aktivitas.

b) Mendesain perencanaan proyek

Perencanaan dilakukan secara kolaboratif antara pengajar dan siswa. Dengan demikian, siswa diharapkan akan merasa "memiliki" atas proyek tersebut.

c) Menyusun jadwal

Pengajar dan siswa secara kolaboratif menyusun jadwal aktivitas dalam menyelesaikan proyek.

d) Memonitor siswa dan kemajuan proyek

Pengajar bertanggungjawab untuk melakukan monitor terhadap aktivitas siswa selama menyelesaikan proyek. e) Menguji hasil

Penilaian dilakukan untuk membantu pengajar dalam mengukur ketercapaian standar, berperan, dan mengevaluasi kemajuan masing-masing siswa, memberi umpan balik tentang tingkat pemahaman yang sudah dicapai pesrta didik, membantu pengajar dalam menyusun strategi pembelajaran berikutnya.

f) Mengevaluasi pengalaman

Pada akhir proses pembelajaran, pengajar dan siswa melakukan refleksi terhadap aktivitas dan hasil proyek yang sudah dijalankan. Proses refleksi dilakukan baik secara individu maupun kelompok. Pada tahap ini, siswa diminta untuk mengungkapkan perasaan dan pengalamannya selama menyelesaikan proyek.

Penilaian pembelajaran dengan model pembelajaran berbasis proyek harus dilakukan secara menyeluruh terhadap sikap, pengetahuan, dan keterampilan yang diperoleh siswa dalam melaksanakan pembelajaran berbasis proyek. Penilaian pembelajaran berbasis proyek dapat menggunakan teknik yang dikembangkan oleh Pusat Penilaian Pendidikan Kementrian Pendidikan dan Kebudayaan (dalam Munirah, 2015: 60) yaitu penilai proyek atau penilai produk. Penilaian tersebut antara lain sebagi berikut:

a) Kemampuan pengelolaan

Kemampuan siswa dalam memilih topik, mencari informasi, dan mengelolah waktu pengumpulan data serta penulisan laporan.

b) Relevansi

Kesesuaian dengan mata pelajaran dengan mempertimbangkan tahap pengetahuan, pemahaman, dan keterampilan dalam pembelajaran.

c) Keaslian

Proyek yang dilakukan siswa harus merupakan hasil karyanya dengan mempertimbangkan kontribusi guru berupa petunjuk dan dukungan terhadap proyek siswa. 
Kemampuan siswa dalam menulis puisi sangatlah bervariatif. Untuk mengetahui tingkat kemampuan siswa dalam menulis puisi, kita harus melihatnya dalam beberapa aspek. Menurut Waluyo (1991: 26), unsur pembangun puisi ada dua, yaitu struktur fisik dan struktur batin. Menurut Wiyanto (dalam Prayitno, 2013: 3), mengemukakan unsur-unsur yang dinilai dalam menulis puisi adalah (a) kesesuaian isi dengan tema, (b) diksi, (c) rima, dan (d) tipografi. Dalam penelitian ini peneliti akan mengkaji puisi dalam segi struktur fisik dan batin agar puisi menjadi baik dan benar. Kemampuan menulis puisi yang yang dinilai, di dalam penelitian ini adalah kesesuaian dengan tema, diksi, pengimajian, bahasa figuratif/gaya bahasa, dan tipografi.

\section{METODE PENELITIAN}

Penelitian ini merupakan penelitian eksperimen, metode eksperimen adalah satu-satunya metode penelitian yang dianggap paling tepat untuk menguji hipotesis mengenai hubungan sebab akibat (Mahmud, 2011: 106). Penelitian ini merupakan penelitian eksperimen yaitu metode penelitian yang digunakan untuk mencari pengaruh perlakuan tertentu terhadap yang lain dalam kondisi yang terkendali. Jenis penelitian ini adalah penelitian pre-eksperimental yang melibatkan satu kelas sebagai kelas eksperimen dengan tujuan untuk mengetahui keefektifan model pembelajaran berbasis proyek terhadap kemampuan menulis puisi siswa kelas VIII SMP Negeri 33 Makassar. Dalam penelitian ini terdiri dari 2 variabel eksperimen yang meliputi:

a) Variabel bebas : penggunaan model pembelajaran berbasis proyek dalam pembelajaran menulis puisi.

b) Variabel terikat : kemampuan menulis puisi siswa kelas VIII SMP Negeri 33 Makassar.

Dalam penelitian ini, variabel yang diteliti yaitu penggunaan model pembelajaran berbasis proyek dan kemampuan menulis puisi pada siswa kelas VIII SMP Negeri 33 Makassar. Penelitian yang digunakan adalah one-grup pretestposttest design yang merupakan bagian dari pra-eVIII perimental design. Pada one-grup pratest-posttest akan dilakukan perbandingan antara hasil nilai prates dan nilai posttest sehingga hasil perlakuan dapat diketahui lebih akurat. One-grup pratestposttest merupakan rancangan eksperimen yang dilakukan pada satu kelompok pembanding. Adapun desainnya dapat digambarkan sebagai berikut:

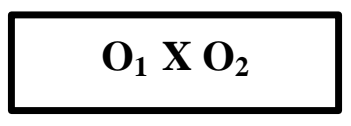

$\mathrm{O}_{1}=$ nilai pratest

$\mathrm{O}_{2}=$ nilai posttest

VIII = perlakuan yang diberikan

Pengaruh perlakuan $=\mathrm{O}_{2}-\mathrm{O}_{1}$

Sumber : Metode Penelitian Pendidikan oleh Sugiyono hal.110 - 111 .

Siswa kelas VIII SMP Negeri 33 Makassar berjumlah 20. Menurut Tiro (2008:), populasi adalah sejumlah orang, benda atau objek lainnya. Jadi, populasi dalam penelitian ini adalah seluruh orang. Penarikan sampel dalam penelitian ini menggunakan teknik total sampling yaitu mengambil keseluruhan jumlah populasi. Jadi, sampel dalam penelitian ini adalah kelas VIII sebanyak 20 siswa.

Definisi operasional variabel pada penelitian ini terdiri dari dua yaitu:

a) Penggunaan model yang diperoleh siswa dari hasil pretest dan posttest yaitu sebelum dan sesudah diterapkannya model pembelajaran berbasis proyek pada pembelajaran bahasa Indonesia.

b) Kemampuan menulis puisi siswa yaitu hasil yang diperoleh siswa dalam mengukur kemampuan menulis puisi sebelum dan sesudah diterapkan model.

Instrumen yang digunakan dalam penelitian ini berupa tes penugasan menulis puisi. Adapun instrumen penelitian sebagai berikut: 
Soal

Tes Hasil Belajar

1. Pilihlah judul dan tema yang menarik!

2. Tuliskan puisi bebas berdasarkan imajinasi. Puisi tersebut harus mengandung beberapa unsur, yaitu:

a. Judul dan Tema

b. Diksi

c. Imaji

d. Bahasa figuratif/ gaya bahasa Tipografi

Teknik pengumpulan data yang digunakan terdiri dari:

\section{Tes/Penugasan}

Tes adalah suatu teknik pengukuran yang di dalamnya terdapat berbagai pertanyaan, pernyataan, atau serangkaian tugas yang harus dikerjakan atau dijawab oleh responden (Arifin, 2011: 226). Dalam teknik ini peneliti memberikan penugasan kepada siswa untuk membuat sebuah puisi. Tes ini dilakukan untuk mengetahui tingkat kemampuan siswa dalam menulis puisi, jika terdapat kekurangan atau hambatan peneliti dapat menindaklanjuti hasil tes tersebut. Hasil tes siswa dalam menulis puisi dapat memberi tahu peneliti mengenai peningkatan kemampuan siswa dalam menulis puisi.

Selain menghitung nilai ketuntasan siswa secara individu, juga diperlukan penilaian ketuntasan secara keseluruhan yang disebut dengan ketuntasan klasikal. Untuk menghitung nilai ketuntasan klasikal maka akan digunakan rumus:

$$
\begin{gathered}
\begin{array}{c}
\text { Penilaian ketuntasan klasikal } \\
=\frac{\text { Jumlah siswa dengan skor } \geq 78}{\text { Jumlah siswa keseluruhan }}
\end{array} 100
\end{gathered}
$$

Sumber : Skripsi Aswar Anas (2016 : 30)

\section{Analisis Inferensial}

Statistik inferensial digunakan untuk menganalisa data sampel dan hasilnya diberlakukan untuk populasi. Teknik ini

\section{Perlakuan (Treatment)}

Memberi perlakuan kepada kelas eksperimen dengan menggunakan model pembelajaran berbasis proyek. Perlakuan tersebut bertujuan untuk mengetahui pengaruh penggunaan model terhadap kemampuan menulis puisi pada siswa.

1. Dokumentasi

Dokumentasi merupakan pengumpulan, pengolahan, dan penyimpanan informasi di bidang pengetahuan (Reality, 2008: 210).

$$
\text { Hasil yang diperoleh dalam }
$$
penelitian ini dianalisis melalui analsis statistik deskriptif. Statistik deskriptif adalah statistik yang digunakan untuk menganalisis data dengan cara mendeskripsikan atau menggambarkan data yang terkumpul. Untuk mengetahui kemajuan hasil belajar siswa secara individu maka terlebih dahulu diperlukan adanya nilai hasil pretest dan posttes. Untuk menghitung nilai hasil pretset dan posttest dari soal yang berbentuk uraian maka digunakan rumus :

$$
g=\frac{\text { skor posttest }- \text { skor pretest }}{\text { skor maksimum ideal }- \text { skor pretest }}
$$

Ket $:$ VIII $=$ Nilai perolehan Siswa

Adapun untuk mengetahui sejauh mana kemajuan hasil belajar siswa antara sebelum dan sesudah penggunaan model pembelajaran berbasis proyek maka digunakan uji gain. Adapun rumus uji gain sebagai berikut:

Table 3.4 kriteria indeks gain

\begin{tabular}{|c|c|}
\hline Nilai $g$ & Interpretasi \\
\hline $0,7 \leq g<1$ & Tinggi \\
\hline $0,3 \leq g<0,7$ & Sedang \\
\hline $0 \leq g<0,3$ & Rendah \\
\hline
\end{tabular}

dimaksudkan untuk menguji hipotesis penelitian. Sebelum pengujian hipotesis, dilakukan uji normalitas. 
a. Uji Normalitas

Uji normalitas digunakan untuk mengetahui apakah daat tentang hasil belajar matematika siswa sebelum dan setelah perlakuan berasal dari populasi yang berdistribusi normal.

Untuk keperluan pengujian normalitas populasi digunakan hipotesis sebagai berikut:

$\mathrm{H}_{0}=$ data berasal dari populasi yang berdistribusi normal

$\mathrm{H}_{1}=$ data berasal dari populasi yang tidak berdistribusi normal

Pada penelitian ini menggunakan taraf signifikan $5 \%$ atau 0,05 dengan syarat:

1) Jika $P_{\text {value }} \geq 0,05$ maka $\mathrm{H}_{0}$ diterima $\mathrm{H}_{1}$ ditolak, artinya data hasil belajar bahasa Indonesia siswa dari kelas yang diberikan perlakuan berasal dari populasi yang berdistribusi normal.

2) Jika $P_{\text {value }}<0,05$ maka $\mathrm{H}_{1}$ diterima $\mathrm{H}_{0}$ ditolak, artinya data hasil belajar bahasa Indonesia siswa dari kelas yang diberikan perlakuan berasal dari populasi yang tidak berdistribusi normal.

\section{b. Uji Hipotesis}

Setelah uji normalitas, selanjutnya dilakukan pengujian hipotesis. Pengujian hipotesis dimaksudkan untuk menjawab hipotesis penelitian yang telah diajukan. Pengujian dilakukan dengan menggunakan uji-t satu sampel (one sample t-test) apabila daat tersebut berdistribusi normal.

1) Pengujian hipotesis minor berdasarkan Kriteria Ketuntasan Minimal (KKM) menggunakan uji kesamaan rata - rata yaitu dengan menerapkan teknik uji-t satu sampel. Secara statistik, maka dirumuskan hipotesis kerja sebagai berikut:

$$
t_{\text {hitung }}=\frac{\bar{x}-\mu_{\mathrm{o}}}{s / \sqrt{n}}
$$

$H_{0}: \mu \leq 77,9$ melawan $H_{1}: \mu>77,9$

$\mu=$ Rata - rata skor hasil belajar siswa
Dengan rumus (Olahdata, $2016: 2$ )

Kriteria pengambilan keputusan adalah : $\mathrm{H}_{0}$ ditolak jika $\mathrm{t}>\mathrm{t}_{(1-\alpha)}$ dan $\mathrm{H}_{0}$ diterima jika $\mathrm{t} \leq \mathrm{t}_{(1-\alpha)}$ dimana $\alpha=5 \%$. Jika $\mathrm{t}>$ $\mathrm{t}(1-\alpha)$ berarti hasil belajar bahasa Indonesia siswa lebih dari 77,9 (KKM $=70$ )

2) Pengujian hipotesis minor berdasarkan gain (peningkatan) menggunakan uji kesamaan rata - rata yaitu dengan menerapkan uji-t satu sampel. Secara statistik, maka dirumuskan hipotesis kerja sebagai berikut:

$H_{0}: \mu_{g} \leq 0,29$ melawan $H_{1}: \mu_{g}>0,29$

$$
t_{\text {hitung }}=\frac{\bar{x}-\mu_{0}}{s / \sqrt{n}}
$$

$\mu_{\mathrm{g}}=$ Parameter skor rata-rata gain ternormalisasi

Dengan rumus (Olahdata, $2016: 2$ )

Kriteria pengambilan keputusan adalah : $\mathrm{H}_{0}$ ditolak jika $\mathrm{t}>\mathrm{t}_{(1-\alpha)}$ dan $\mathrm{H}_{0}$ diterima jika $\mathrm{t} \leq \mathrm{t}_{(1-\alpha)}$ dimana $\alpha=5 \%$. Jika $\mathrm{t}>$ $\mathrm{t}_{(1-\alpha)}$ berarti peningkatan hasil belajar bahasa Indonesia siswa lebih dari 0,29.

3) Pengujian hipotesis minor berdasarkan Ketuntasan klasikal menggunakan uji kesamaan rata - rata yaitu dengan menerapkan uji-t satu sampel. Secara statistik, maka dirumuskan hipotesis kerja sebagai berikut:

$H_{0}: \pi \leq 69,9$ melawan $H_{1}: \pi>69,9$

$\pi=$ Parameter ketuntasan belajar bahasa Indonesia secara klasikal

$$
\mathbf{z}=\frac{\mathbf{x} / \mathbf{n}-\mathbf{p}_{\mathbf{o}}}{\sqrt{\frac{\mathbf{p}_{\mathbf{o}}\left(\mathbf{1}-\mathbf{p}_{\mathbf{o}}\right)}{\mathbf{n}}}}
$$

Dengan rumus (Uji Hipotesis Lanjutan : 1)

Kriteria pengambilan keputusan adalah $: \mathrm{H}_{0}$ ditolak jika $\mathrm{z}>\mathrm{z}_{(1-\alpha)}$ dan $\mathrm{H}_{0}$ diterima 
jika $\mathrm{z} \leq \mathrm{z}_{(1-\alpha)}$ dimana $\alpha=5 \%$. Jika $\mathrm{z}$ $>\mathrm{Z}_{(1-\alpha)}$ berarti peningkatan hasil

\section{PEMBAHASAN}

Penelitian ini bertujuan untuk menguji keefektifan model pembelajaran berbasis proyek terhadap kemampuan menulis puisi siswa kelas VIII SMP Negeri 33 Makassar. Data-data penelitian ini diperoleh dari nilai hasil belajar sebelum perlakuan (pre-tes) untuk mengetahui kemampuan menulis puisi siswa dan skor postes untuk mengetahui kemampuan puisi siswa berdasarkan kesesuaian isi dengan tema, imaji, diksi, bahasa figuratif/gaya bahasa, dan tipografi dengan menggunakan model pembelajaran berbasis proyek.

\section{a. Hasil Analisis Deskriptif}

1) Analisis Deskriptif Hasil Belajar Kemampuan Menulis Puisi Tanpa Menggunakan Model Pembelajaran belajar bahasa Indonesia siswa lebih dari 69,9 (Ketuntasan Klasikal $=70)$

Berbasis Proyek Siswa kelas VIII SMP Negeri 33 Makassar. (Pretest)

Berdasarkan analisis data pretest kemampuan menulis puisi tanpa menggunakan model pembelajaran dengan 20 siswa diperoleh gambaran bahwa tidak ada siswa yang mampu memperoleh nilai 100 sebagai nilai ideal. Nilai tertinggi hanya 80 yang diperoleh 1 orang dan nilai terendah adalah 40 yang diperoleh 2 orang siswa.

Berdasarkan hal tersebut, maka gambaran yang lebih jelas dan tersusun rapi yang diperoleh siswa beserta frekuensi dapat dilihat pada tabel 4.1 dan tabel 4.2. Selain itu, pada tabel 4.1 dipaparkan data tabel 4.2 dipaparkan perolehan nilai siswa dan secara umum tentang distribusi nilai, frekuensi, dan persentase kemampuan menulis puisi tanpa menggunakan model pembelajaran.

Tabel 4.1 Data Skor Mentah Hasil Perolehan Siswa Terhadap Kemampuan Menulis Puisi Tanpa Menggunakan Model Pembelajaran Berbasis Proyek. (Pretest)

\begin{tabular}{|c|c|c|c|c|c|c|}
\hline No. & \multicolumn{7}{|c|}{ Skor } & Jumlah skor \\
\cline { 2 - 6 } Resp & Tema & Diksi & Imaji & Bahasa Figuratif & Tipografi & \\
& $1-5$ & $1-5$ & $1-5$ & $1-5$ & 2 & \\
\hline 1 & 3 & 3 & 3 & 1 & 4 & 48 \\
2 & 4 & 3 & 3 & 2 & 2 & 64 \\
3 & 3 & 2 & 2 & 1 & 4 & 40 \\
4 & 4 & 3 & 3 & 2 & 4 & 72 \\
5 & 3 & 4 & 4 & 3 & 3 & 76 \\
6 & 4 & 4 & 5 & 3 & 3 & 56 \\
7 & 3 & 3 & 3 & 2 & 3 & 64 \\
8 & 4 & 4 & 3 & 2 & 4 & 40 \\
9 & 2 & 2 & 2 & 1 & 3 & 80 \\
10 & 4 & 5 & 4 & 3 & 4 & 74 \\
11 & 3 & 2 & 2 & 1 & 4 & 68 \\
12 & 4 & 5 & 4 & 2 & 3 & 60 \\
13 & 4 & 4 & 3 & 2 & 5 & 84 \\
14 & 3 & 3 & 4 & 3 & 4 & 72 \\
15 & 3 & 3 & 3 & 3 & & \\
16 & 4 & 4 & 5 & 2 & 3 & \\
17 & 4 & 4 & 4 & & 3 & \\
\hline
\end{tabular}




\begin{tabular}{|l|l|l|l|l|l|l|}
\hline 18 & 3 & 3 & 3 & 1 & 3 & 52 \\
19 & 3 & 3 & 3 & 1 & 3 & 52 \\
20 & 3 & 3 & 2 & 1 & 2 & 44 \\
\hline
\end{tabular}

Berdasarkan tabel 4.1 di atas, akan dibuat tabel distribusi frekuensi kemampuan menulis puisi tanpa menggunakan model, yaitu sebagai berikut.

Tabel 4.2 Daftar Nilai Distribusi Frekuensi dan Persentase Kemampuan Menulis Puisi Tanpa Menggunakan Model Pembelajaran Berbasis Proyek (pretest)

\begin{tabular}{|c|c|c|c|}
\hline No & Nilai & Frekuensi & Persentase (\%) \\
\hline 1 & 84 & 1 & 5 \\
2 & 80 & 1 & 5 \\
3 & 76 & 2 & 10 \\
4 & 72 & 2 & 10 \\
5 & 68 & 1 & 5 \\
6 & 64 & 3 & 15 \\
7 & 60 & 2 & 10 \\
8 & 56 & 1 & 5 \\
9 & 52 & 2 & 10 \\
10 & 48 & 1 & 5 \\
11 & 44 & 2 & 10 \\
12 & 40 & 2 & 10 \\
\hline
\end{tabular}

Berdasarkan tabel 4.2 menunujukkan bahwa skor tertinggi diperoleh 1 siswa dengan skor 84 dengan presentase $(5 \%)$.S elanjutnya, skor 80 diperoleh 1 siswa dengan persentase (5\%). Skor 76 diperoleh 2 siswa dengan persentase (10\%). Skor 72 diperoleh 2 siswa dengan persentase (10\%). Skor 68 diperoleh 1 siswa dengan persentase (5\%). Skor 64 diperoleh 3 siswa dengan persentase (15\%). Skor 60 diperoleh 2 siswa dengan persentase (10\%). Skor 56 diperoleh 1 siswa dengan persentase (5\%). Skor 52 diperoleh 2 siswa dengan persentase (10\%). Skor 48 diperoleh 1 siswa dengan persentase (5\%), Skor 44 diperoleh
2 siswa dengan persentase (10\%). Skor 40 diperoleh 2 siswa dengan persentase (10\%).

Berdasarkan uraian tersebut tampak bahwa perolehan nilai siswa berada pada rentang nilai 40-84 dari rentang 10-100 yang kemungkinan dapat diperoleh siswa. Berdasarkan perolehan skor, nilai beserta frekuensi dapat diketahui tingkat kemampuan menentukan pembangun puisi tanpa menggunakan model pembelajaran berbasis proyek terhadap kemampuan menulis puisi siswa kelas VIII SMP Negeri 33 Makassar. Untuk lebih jelasnya, lihatlah tabel berikut ini.

Tabel 4.3 Klasifikasi Nilai Siswa (pretest)

\begin{tabular}{|l|l|l|l|}
\hline No & Perolehan Nilai & Frekuensi (f) & Persentase (\%) \\
\hline 1 & Nilai 70 ke atas & 6 & 30 \\
\hline 2 & Nilai di bawah 70 & 14 & 70 \\
\hline Jumlah & & 20 & 100 \\
\hline
\end{tabular}


Berdasarkan tabel 4.3 di atas, dapat diketahui bahwa frekuensi dari persentase nilai kemampuan menulis puisi tanpa menggunakan model pembelajaran berbasis proyek siswa kelas VIII SMP Negeri 33 Makassar, yaitu siswa yang mendapat nilai 70 ke atas sebanyak 6 siswa $(30 \%)$ dari jumlah sampel, sedangkan siswa yang mendapat nilai di bawah 70 sebanyak 14 siswa (70\%) dari jumlah sampel. Dengan demikian, dapat dinyatakan bahwa kemampuan menulis siswa tanpa menggunakan model pembelajaran berbasis proyek siswa kelas VIII SMP Negeri 33 Makassar belum memadai karena nilai yang mencapai kriteria yang ditetapkan sebagai kriteria kemampuan siswa yaitu hanya $30 \%$ atau sebanyak 6 siswa.

\section{2) Analisis Deskriptif Hasil Belajar Kemampuan Menulis Puisi}

Menggunakan Model Pembelajaran Berbasis Proyek Siswa kelas VIII SMP Negeri 33 Makassar. (Posttest)

Berdasarkan analisis data posttest kemampuan menentukan kemampuan menulis puisi menggunakan model pembelajaran berbasis proyek dengan jumlah 20 siswa (lihat lampiran), yaitu ada 2 siswa yang memperoleh skor 92 sebagai skor tertinggi dan skor terendah adalah 68 yang diperoleh 2 siswa.

Berdasarkan hal tersebut, maka gambaran yang lebih jelas dan tersusun rapi yang diperoleh siswa beserta frekuensi dapat dilihat pada tabel 4.4 dan tabel 4.5. Selain itu, pada tebel 4.4 dipaparkan data tabel 4.5 dipaparkan perolehan nilai siswa dan secara umum tentang distribusi nilai, frekuensi, dan persentase kemampuan menulis puisi menggunakan model pembelajaran berbasis proyek.

Tabel 4.4 Data Skor Mentah Hasil Perolehan Siswa Kemampuan Menulis Puisi Menggunakan Model Pembelajaran Berbasis Proyek. (Posttest)

\begin{tabular}{|c|c|c|c|c|c|c|}
\hline No. & \multicolumn{7}{|c|}{ Skor } & Jumlah skor \\
\cline { 2 - 6 } Resp & Tema & Diksi & Imaji & Bahasa Figuratif & Tipografi & \\
& $1-5$ & $1-5$ & $1-5$ & $1-5$ & $4-5$ & \\
\hline 1 & 3 & 4 & 4 & 3 & 4 & 72 \\
2 & 4 & 4 & 4 & 3 & 4 & 76 \\
3 & 3 & 4 & 4 & 3 & 4 & 72 \\
4 & 5 & 5 & 5 & 4 & 4 & 82 \\
5 & 4 & 5 & 5 & 3 & 4 & 80 \\
6 & 4 & 5 & 5 & 3 & 3 & 68 \\
7 & 4 & 4 & 4 & 2 & 4 & 76 \\
8 & 4 & 4 & 4 & 3 & 4 & 72 \\
9 & 4 & 4 & 4 & 2 & 4 & 84 \\
10 & 4 & 5 & 5 & 3 & 3 & 68 \\
11 & 3 & 4 & 5 & 2 & 4 & 80 \\
12 & 4 & 5 & 5 & 3 & 4 & 76 \\
13 & 4 & 5 & 4 & 2 & 4 & 72 \\
14 & 4 & 4 & 4 & 2 & 4 & 84 \\
15 & 4 & 5 & 4 & 4 & 5 & 92 \\
16 & 5 & 5 & 5 & 3 & 4 & 84 \\
17 & 4 & 5 & 5 & 3 & 4 & 76 \\
18 & 4 & 4 & 4 & 3 & 4 & 80 \\
19 & 4 & 4 & 4 & 3 & 4 & 72 \\
20 & 4 & 4 & 3 & 3 & & \\
\hline
\end{tabular}


Berdasarkan tabel 4.4 di atas, akan

menulis puisi menggunakan media yaitu sebagai berikut. dibuat tabel distribusi frekuensi kemampuan

Tabel 4.5 Daftar Nilai Distribusi Frekuensi dan Persentase Kemampuan Menulis Puisi Menggunakan Model Pembelajaran.(pretest)

\begin{tabular}{|c|c|c|c|}
\hline No & Nilai & Frekuensi & Persentase $(\%)$ \\
\hline 1 & 92 & 2 & 10 \\
2 & 84 & 4 & 20 \\
3 & 80 & 3 & 15 \\
4 & 76 & 4 & 20 \\
5 & 72 & 5 & 25 \\
6 & 68 & 2 & 10 \\
\hline
\end{tabular}

Berdasarkan tabel 4.2 menunjukkan bahwa skor tertinggi diperoleh 2 siswa dengan jumlah skor 92 dengan nilai 92 (10\%). Selanjutnya, skor 84 diperoleh 4 siswa dengan persentase (20\%). Skor 80 diperoleh 3 siswa dengan persentase $(15 \%)$, skor 76 diperoleh 4 siswa dengan persentase (20\%). Skor 72 diperoleh 5 siswa dengan persentase $(25 \%)$, dan skor 68 diperoleh 2 siswa dengan persentase (10\%).
Berdasarkan uraian tersebut tampak bahwa perolehan nilai siswa berada pada rentang nilai 68-92 dari rentang 10-100 yang kemungkinan dapat diperoleh siswa. Berdasarkan perolehan skor, nilai beserta frekuensi dapat diketahui tingkat kemampuan menulis puisi menggunakan model pembelajaran berbasis proyek siswa kelas VIII SMP Negeri 33 Makassar (posttest). Untuk lebih jelasnya, lihatlah tabel berikut ini.

Tabel 4.6 Klasifikasi Nilai Siswa (pretest)

\begin{tabular}{|c|c|c|c|}
\hline No & Perolehan Nilai & Frekuensi (f) & Persentase (\%) \\
\hline 1 & Nilai 70 ke atas & 18 & 90 \\
\hline 2 & Nilai di bawah 70 & 2 & 10 \\
\hline & Jumlah & 20 & 100 \\
\hline
\end{tabular}

Berdasarkan tabel 4.6 di atas, dapat diketahui bahwa frekuensi dari persentase nilai kemampuan menulis puisi menggunakan model pembelajaran berbasis proyek siswa kelas VIII SMP Negeri 33 Makassar(posttest), yaitu siswa yang mendapat nilai 70 ke atas sebanyak 18 siswa (90\%) dari jumlah sampel, sedangkan siswa yang mendapat nilai di bawah 70 sebanyak 2 siswa (10\%) dari jumlah sampel.

Dengan demikian, dapat dinyatakan bahwa kemampuan menulis puisi menggunakan model pembelajaran berbasis proyek siswa kelas VIII SMP Negeri 33 Makassar (posttest) dikategorikan sudah memadai. Hal ini, dinyatakan karena siswa yang memperoleh nilai $70 \mathrm{ke}$ atas mencapai kriteria yang ditetapkan yaitu $85 \%$.

\section{b. Hasil Analisis Inferensial}

Pembahasan hasil analisis statistik inferensial yang dimaksudkan disini adalah pembahasan terhadap hasil pengujian hipotesis yang telah dirumuskan sebelumnya. Hasil analisis statistik inferensial menunjukkan bahwa skor rata rata hasil belajar siswa setelah diterapkannya model pembelajaran berbasis proyek tampak nilai $\mathrm{p}$ (sig 2-tailed) adalah $0,000<0,05$ sehingga dapat disimpulkan bahwa H0 ditolak dan $\mathrm{H} 1$ diterima yang berarti bahwa rata - rata hasil belajar siswa $\geq 70$. 
Hasil analisis inferensial juga menunjukkan bahwa rata - rata gain ternormalisasi tampak bahwa nilai sig. (2tailed) adalah 0,000 yang mana 0,000< 0,05 sehingga dapat disimpulkan bahwa $\mathrm{H} 0$ ditolak dan $\mathrm{H} 1$ diterima yang berarti bahwa rata - rata peningkatan hasil belajar siswa $\geq$ 30. Selain itu hasil analisis statistik inferensial juga menunjukkan bahwa pengujian ketuntasan siswa secara klasikal yang dilakukan dengan menggunakan uji proporsi dengan taraf signifikan 5\% diperoleh $\mathrm{Z}$ tabel $=1,64$ yang mana $\mathrm{H}_{0}$ diterima jika $Z$ hitung $\leq 1,64$. Karena diperoleh nilai $Z$ hitung sebesar 2,017 maka $\mathrm{H}_{1}$ diterima dan $\mathrm{H}_{0}$ ditolak yang berarti ketuntasan siswa secara klasikal $\geq$ 85\%.Sehingga dapat disimpulkan bahwa penggunaan model pembelajaran berbasis proyek terhadap kemampuan menulis puisi memenuhi kriteria efektif.

\section{PENUTUP}

Berdasarkan hasil analisis deskriptif data penelitian ini, dapat diuraikan temuan yang diperoleh yaitu hasil analisis data pretest diketahui bahwa kemampuan menulis puisi siswa kelas VIII SMP Negeri 33 Makassar belum memadai karena jumlah siswa yang mendapat nilai $70 \mathrm{ke}$ atas belum mencapai $85 \%$ dan kemampuan menulis puisi posttest sudah memadai karena jumlah siswa yang mendapat nilai 70 ke atas sudah mencapai $85 \%$. Oleh karena itu, dapat dinyatakan bahwa penggunaan model pembelajaran berbasis proyek efektif diterapkan dalam menulis puisi.

Hasil analisis statistik inferensial menunjukkan bahwa skor rata - rata hasil belajar siswa setelah diterapkan model pembelajaran berbasis proyek tampak nilai $\mathrm{p}$ (sig 2-tailed) adalah 0,000 $<0,05$ sehingga dapat disimpulkan bahwa $\mathrm{H}_{0}$ ditolak dan $\mathrm{H}_{1}$ diterima yang berarti bahwa rata - rata hasil belajar siswa $\geq 70$. Hasil analisis inferensial juga menunjukkan bahwa rata - rata gain ternormalisasi tampak bahwa nilai sig. (2-tailed) adalah
0,000 yang mana $0,000<0,05$ sehingga dapat disimpulkan bahwa $\mathrm{H}_{0}$ ditolak dan $\mathrm{H}_{1}$ diterima yang berarti bahwa rata - rata peningkatan hasil belajar siswa $\geq 30$. Selain itu, hasil analisis statistik inferensial juga menunjukkan bahwa pengujian ketuntasan siswa secara klasikal yang dilakukan dengan menggunakan uji proporsi dengan taraf signifikan 5\% diperoleh $\mathrm{Z}$ tabel $=1,64$ yang mana $\mathrm{H}_{0}$ diterima jika $\mathrm{Z}$ hitung $\leq 1,64$. Karena diperoleh nilai $\mathrm{Z}$ hitung sebesar 2,017 maka $\mathrm{H}_{1}$ diterima dan $\mathrm{H}_{0}$ ditolak yang berarti ketuntasan siswa secara klasikal $\geq$ $85 \%$, sehingga dapat disimpulkan bahwa penggunaan model pembelajaran berbasis proyek terhadap kemampuan menulis puisi memenuhi kriteria efektif.

\section{REFERENSI}

Arifin, Zaenal. 2011. Penelitian Pendidikan. Bandung: Remaja Rosdakarya.

Arikunto, Suharsimi. 1992. Prosedur Penelitian suatu Pendekatan Praktik. Jakarta: Rineka Cipta.

Arsyad, Azhar. 2014. Media Pembelajaran. Jakarta: Raja Grafindo Persada.

Aqib, Zainal. 2013. Model-Model, Media, dan Strategi Pembelajaran Kontekstual (Inovatif). Bandung: Yrama Widya.

Badan Pusat Statistik. 2015. Indeks Pembangunan Manusia 2014. Jakarta: Badan Pusat Statistik.

Depdiknas, 2006. Kurikulum 2006 KTSP Mata Pelajaran Bahasa Indonesia. Jakarta: Depdiknas.

Djupriyanto dkk. 1992. Pelajaran Apresiasi Bahasa Indonesia dan Sastra Indonesia SMA Edisi Pertama. Surabaya: Kendang Sari.

Kartia. 2014. Efektivitas Pembelajaran Matematika dengan Pendekatan Kontekstual pada Siswa Kelas VIII SMP PGRI Sungguminasa Kabupaten Gowa. Skripsi tidak diterbitkan. Makassar: FKIP Unismuh. 
Kurniasi, Imas. 2016. Revisi Kurikulum 2013. Jakarta: Kata Pena.

Nurgiyantoro, Burhan. 1995. Penilaian Pengajaran Bahasa dan Sastra.Yogjakarta: BPFE.

Noname. Uji_Hipotesis_Lanjutan.

(Download). http://file.upi.edu/Direktori/FPMIP A/JUR. PEND. FISIKA/1958030119 $\underline{8}$ 0021-

PARSAORAN_SIAHAAN/Present asi_Kuliah/Uji_Hipotesis_Lanjutan.pd

f. Diakses : 7 juni 2017.

Mahmud. 2011. Metodologi Penelitian Pendidikan. Bandung: Pustaka Setia.

Munandi. 2013. Media Pembelajaran. Jakarta: Referensi.

Olahdata. 2016. Uji-T-Satu-Sampell.pdf. (Download). http://www.

Swanstatistcs.com/wpcontent/uploads/2016/10/UJI-T-

SATU-

SAMPELL.pdf\&sa=U\&ved=0ahU KEwjcobzq-

pzUAhVFQ18KHZwTChMQFggo MAA\&usg=AfQjCNHOEOEEe6nMC - C9_c27yQuQQ7Nj1Q. Diakses : 1 Juni 2017.

Pradopo, Rachmat Djoko. 2012. Pengkajian Puisi. Yogyakarta: Gadjah Mada Universitiy Press.

Prayitno, Hendi Waluyo. 2013. "Peningkatan Keterampilan Menulis Puisi Menggunakan Teknik Inkuiri dan Latihan Terbimbing", Jurnal PendidikanBahasa dan Sastra Indonesia, Volume 2, No.1.

Priyatno, Duwi. 2010. Teknik Mudah dan Cepat Melakukan Analisis Data Penelitian dengan SPSS dan Tanya Jawab Ujian Pendadaran. Yogyakarta: Gaya Media.

Purwanto. 2008. Metodologi Penelitian Kuantitatif untuk Psikologi dan Pendidikan. Yogyakarta: Pustaka.

Rimang, St. Suwadah. 2011. Kajian Sastra Teori dan Praktik. Makassar: Aura Pustaka.
Rusman. 2016. Model-Mode Pembelajaran. Jakarta: Rajawali Pers.

Sugiyono. 2003. Statistik untuk Penelitian. Bandung: Alfabeta.

Sumardjo, Jakob dan Saini K.M. 1991. Apresiasi Kesusastraan. Jakarta: Gramedia Pustaka Utama.

Syarif. 2015. Keefektifan Metode Pembelajaran Kooperatif Tipe Bercerita Berpasangan (Paired Story Telling) Dalam Menentukan UnsurUnsur Intrinsik Cerpen Siswa Kelas VIII Mts Muhammadiyah Laiya Kecamatan Cenrana Kabupaten Maros. Skripsi. Makassar: FKIP:Universitas Muhammadiyah Makassar.

Tiro. 2008. Dasar-Dasar Statistika. Makassar: Andira Publisher.

Tarigan, Henry Guntur. 2008. Menulis sebagai Suatu Keterampilan Berbahasa. Bandung: Angkasa.

Waluyo, Herman J. 2003.Apresiasi Puisi untuk Pelajar dan Mahasiswa. Jakarta, Gramdia Pustaka Utama.

Yulianto, Agus. 2015. Penelitian Tindak Kelas dengan Metode Mutakhir. Yogyakarta: Andi. 